\title{
Diversity and Abundance of Earthworms in Cocoa Plantations with Different Shade Trees
}

\author{
Niken Puspita Sari ${ }^{1 *}$, Rahayu Widyastuti ${ }^{2)}$ and Soetanto Abdoellah ${ }^{1)}$ \\ ${ }^{1)}$ Indonesian Coffee and Cocoa Research Institute (ICCRI), Jl. PB Sudirman 90, Jember, Indonesia \\ ${ }^{2)}$ Institut Pertanian Bogor, J1. Raya Dramaga Kampus IPB Dramaga, Bogor, Indonesia \\ Corresponding author: niken.iccri@gmail.com \\ Received: 5 October 2021 / Accepted: 18 November 2021
}

\begin{abstract}
Earthworm is one of the important macro-fauna in cocoa plantation ecosystem that affects the structure and activity of soil microbes. Earthworms maintain nutrient cycle and affect the growth of plants. Cocoa is a plant that requires shade trees. The presence of shade trees is to increase soil fertility and enrich diversity of flora and fauna. The purpose of this study was to investigate the diversity and abundance of earthworms in cocoa farms with different shade trees, namely paranet, areca palm + leucaena, coconut + leucaena, oil palm + leucaena, and leucaena. The study was carried out in Kaliwining Experimental Station of Indonesian Coffee and Cocoa Research Institute, Jember. Earthworms were picked manually to a depth of $30 \mathrm{~cm}$ by purposive sampling method from July to October 2020. The cocoa plants used were mature plants with a spacing of $3 \mathrm{~m} \times 3 \mathrm{~m}$. Based on Shannon and Wiener formula, the results showed that earthworm diversity was low in all treatments. Earthworms until family level were identified. Earthworm families of Glososscolicidae and Megascolocidae were found in this study. The highest abundance of earthworms was found in areca palm + leucaena. Soil organic $\mathrm{C}$ and $\mathrm{N}$ content and sand fraction were positively correlated with earthworm abundance, while silt fraction and soil density were negatively correlated with earthworm abundance. As micro-climate factor, light intensity was positively correlated with earthworm abundance, while air temperature was negatively correlated with earthworm abundance.
\end{abstract}

Keywords: earthworm, cocoa, shade tree, diversity, abundance

\section{INTRODUCTION}

Earthworms are one of the important macrofauna in cocoa plantation ecosystem and have functions as decomposers and ecosystem engineers. The interaction between earthworms and cocoa plants is mutual beneficial. The secretions of earthworms contain many nutrients that give benefit to cocoa plants, as well as the movement of earthworms causing the soil to become more porous. Earthworms may affect soil structure, and soil microbial activity. Earthworms maintain the nutrient cycle of soil, consequently they affect plant growth (Kilowasid et al., 2012). Earthworms have a big role. Gamasika et al. (2017) reported that earthworm release 150 ppm of available phosphorus. Earthworms are able to stabilize soil structure, reduce soil bulk density, increase porosity, soil aeration, and soil infiltration (Endarwati et al., 2017). However, the presence of earthworms is influenced by humidity, temperature, $\mathrm{pH}$, and soil organic matter (Satcell, 1967 cit. Firmansyah, 2017). 
Soil fertility in cocoa plantations is inseparable from human and natural activities. Therefore, efforts are needed to maintain the continuity of interactions or relationships between soil, plants, and soil organisms in cocoa plantation ecosystems. Sustainability of nutrient cycle, cocoa productivity, and the existence of soil organisms must be maintained because the threat of soil fertility degradation is a major problem in Indonesia. Hazriyal et al. (2015) reported that organic soil carbon content in cocoa plantations in Peudawa and Peunaron Districts, East Aceh Regency was low to moderate, namely 0.22 $2.23 \%$.

Cocoa is crop that needs shade trees which may increase soil fertility and enrich diversity of soil flora and fauna. Litter fall from shade tree plays a role in the cycle of organisms in soil, especially earthworms. Litter fall from shade tree is a source of food for earthworms. The presence of shade trees plays an important role also in maintaining microclimate which has effect on the earthworms population. Indirectly, the presence of shade trees contributes to the food source for earthworms. Many studies on the diversity and abundance of earthworms have been done, however, few studies have been done in cocoa plantations with different shade trees, especially in the dry season. The purpose of this study was to investigate the diversity and abundance of earthworms and the relationship between soil and micro climate factors with the abundance of earthworms in cocoa plantations with different shade trees.

\section{MATERIALS AND METHODS}

The research was carried out at the Kaliwining Experimental Station, and Soil and Water Laboratory of Indonesian Coffee and Cocoa Research Institute, Jember, East Java, from July 2020 to October 2020. The research site has D climate type (Schmidt \& Ferguson) and Inceptisols soil order. Sampling of earthworms and soil was carried out at five locations as treatments, namely control (cocoa + paranet), cocoa + coconut + leucaena, cocoa + oil palm + leucaena, cocoa + areca palm + leucaena, cocoa + leucaena (Table 1). Maintenance of cocoa and shade tree includes pruning, fertilizing, pest and disease controling which is carried out routinely according to agricultural practices of Kaliwining Experimental Station. Each location was repeated three times. Each replication consisted of 7 samples of cocoa trees resulted that each block consisted of 21 samples and the total sample trees were 105 .

\section{Earthworm Sampling}

Earthworm sampling points were placed under the cocoa canopy with a size of $50 \mathrm{~cm}$ x $50 \mathrm{~cm}$ x $30 \mathrm{~cm}$ which was divided into 3 layers, namely $0-10 \mathrm{~cm}, 10-20 \mathrm{~cm}$, and 20-30 cm. Earthworm samples were taken

Table 1. The description of experimental site

\begin{tabular}{|c|c|}
\hline Experimental site & Description \\
\hline Control (cocoa + paranet) & Planting area $3.000 \mathrm{~m}^{2}$, cocoa distance $3 \mathrm{~m} \mathrm{x} 3 \mathrm{~m}$, planting year 2015 . \\
\hline Cocoa + leucaena + coconut & $\begin{array}{l}\text { Planting area } 8.000 \mathrm{~m}^{2} \text {, cocoa distance } 3 \mathrm{~m} \times 3 \mathrm{~m} \text {, shade distance } 12 \times 15 \mathrm{~m} \text {, planting year } \\
\text { 2014. }\end{array}$ \\
\hline Cocoa + leucaena + oil palm & $\begin{array}{l}\text { Planting area } 10.000 \mathrm{~m}^{2} \text {, cocoa distance } 3 \mathrm{~m} \mathrm{x} 3 \mathrm{~m} \text {, shade distance } 7.5 \times 14 \mathrm{~m} \text {, planting } \\
\text { year } 2014 \text {. }\end{array}$ \\
\hline Cocoa + leucaena + areca palm & $\begin{array}{l}\text { Planting area } 10.000 \mathrm{~m}^{2} \text {, cocoa distance } 3 \mathrm{~m} \mathrm{x} 3 \mathrm{~m} \text {, shade distance } 2 \times 4 \mathrm{~m} \text {, planting year } \\
\text { 2014. }\end{array}$ \\
\hline Cocoa + leucaena & $\begin{array}{l}\text { Planting area } 20.000 \mathrm{~m}^{2} \text {, cocoa distance } 3 \mathrm{~m} \mathrm{x} 3 \mathrm{~m} \text {, shade distance } 3 \times 3 \mathrm{~m} \text {, planting year } \\
\text { 2013. }\end{array}$ \\
\hline
\end{tabular}


from the sampling point following BPT (2007), namely by using a $0.2-0.4 \%$ formalin solution to the entire soil surface, then earthworms were taken by hand, and cleaned from soil. The collected earthworms were then put into labeled glass bottles and filled with $5 \%$ formalin hence that the earthworms were long-lasting and easy to be identified.

\section{Soil Sampling}

Soil samples for chemical and physical analysis were taken from the location of the earthworm sampling point. Soil samples were taken using a soil drill at the depth of $30 \mathrm{~cm}$. The sample then put into a plastic bag and labeled. The soil samples were then analyzed at the Soil and Water Laboratory, Indonesian Coffee and Cocoa Research Institute. Soil analysis parameters were organic $\mathrm{C}$ (Walkey \& Black method), $\mathrm{pH} \mathrm{H}_{2} \mathrm{O}$ ( $\mathrm{pH}$ meter method), total $\mathrm{N}$ (Kjeldahl method), Ca (AAS method), bulk density (sampling ring method), particle density (pycnometer method), and soil porosity.

\section{Climate Observation}

Macro-climate observation used daily collected data at Kaliwining Climatology Station, Indonesian Coffee and Cocoa Research Institute. The observed macroclimate is rainfall, while the microclimate include soil temperature, air temperature, soil moisture, air humidity, and light intensity. Microclimate measurements were carried out at the same day when observing earthworms using a thermohygrometer (to measure air temperature and humidity), a soil thermometer (to measure soil temperature), and lux meter (to measure light intensity). The microclimate observation point was close to the sampling point for earthworms.

\section{Earthworm Identification}

Earthworms that have been obtained were counted in number (individual. $\mathrm{m}^{-2}$ ) and weighed to determine their biomass $\left(\mathrm{g} . \mathrm{m}^{-2}\right)$. The collected earthworms were identified following the instructions made by Hairiah \& Karima (2017) to the family level. Identification of earthworms was carried out at Soil and Water Laboratory, ICCRI, using a stereo microscope with magnification of $40 \mathrm{X}$.

\section{Earthworm Diversity}

Earthworm diversity based on ShannonWiener diversity index ( $\left.\mathrm{H}^{\prime}\right)$ to the family level, using the folowing formula (Odum, 1993):

$$
\begin{aligned}
& H^{\prime}=-\sum\left(\frac{n i}{N}\right) \ln \left(\frac{n i}{N}\right) \\
& =\text { Shanoon-Wiener diversity index } \\
& =\text { Number of individuals i } \\
& =\text { natural logarithm } \\
& =\text { Total number of individuals }
\end{aligned}
$$

The categories for the assessment of

\begin{tabular}{|c|c|c|c|c|c|c|c|c|}
\hline Cocoa shade type & $\begin{array}{c}\mathrm{C} \\
(\%)\end{array}$ & $\begin{array}{c}\mathrm{N} \\
(\%)\end{array}$ & $\mathrm{C} / \mathrm{N}$ & $\mathrm{pH}$ & $\begin{array}{c}\mathrm{Ca} \\
(\mathrm{me} \%)\end{array}$ & $\begin{array}{c}\text { Bulk } \\
\text { density } \\
\left(\text { g. } \mathrm{cm}^{-3}\right)\end{array}$ & $\begin{array}{l}\text { Particle } \\
\text { density } \\
\left(\mathrm{g} . \mathrm{cm}^{-3}\right)\end{array}$ & $\begin{array}{c}\text { Porosity } \\
(\%)\end{array}$ \\
\hline Control (paranet) & 0.79 & 0.10 & 8.31 & 6.15 & 11.3 & 1.30 & 1.99 & 38.9 \\
\hline Cocoa + leucaena + coconut & 1.52 & 0.17 & 9.31 & 6.05 & 14.9 & 1.22 & 1.84 & 39.0 \\
\hline Cocoa + leucaena + oil palm & 1.21 & 0.13 & 9.73 & 6.56 & 15.0 & 1.18 & 1.88 & 37.1 \\
\hline Cocoa + leucaena + areca palm & 1.53 & 0.18 & 8.42 & 6.24 & 12.4 & 1.21 & 1.86 & 39.6 \\
\hline Cocoa + leucaena & 1.32 & 0.16 & 8.48 & 6.17 & 15.6 & 1.15 & 1.86 & 38.1 \\
\hline
\end{tabular}
the diversity index are as follows: $a . H^{\prime}<2$ : low, b. H' = 2-3: moderate c. H'>4: high.

Table 2. Soil chemical and physical characteristics in each experimental site of cocoa plantations with several shade trees 
Analysis of earthworm diversity used ANOVA with $95 \%$ confidence level. To determine the relation between the physical and chemical properties of the soil with the abundance of earthworms, Pearson correlation analysis $5 \%$ was used.

\section{RESULTS AND DISCUSSION}

\section{Earthworm Diversity}

The diversity of identified earthworms in cocoa plantations with several shade patterns based on Odum (1993) was low (Figure 1). This low diversity index value was caused by only two identified families of earthworms. Besides, the experiment was carried out during dry season periode. This study was similar to Wibowo (2016) where the season determines the diversity of earthworms and only four species of worms during the dry season and seven species during rainy season. The low diversity of earthworms in cocoa plantations with several shade patterns was caused by the dominance of the earthworm family. The found earthworm families were Glossoscolicidae and Megascolicidae. The Glossoscolecidae family was dominant in all of shade pattern studied. The identified family Glossoscolicidae was the species Pontoscolex corethrurus. According to Setyaningsih et al. (2014) Pontoscolex corethrurus is highly adaptable to various environmental conditions. Meanwhile, Megascolocidae family was only found in cocoa farms with paranet or control shading. The identified species of this family was Pheretima sp. (Table 2). Earthworm diversity is influenced by environmental changes, quality of nutrients and energy sources, seasonal changes, biotic interactions with communities, and climate change (Dewi $\&$ Senge, 2015). Earthworm diversity is not only influenced by the dominance of a species, but also determined by soil organic matter content. Nurrohman et al. (2018) stated that the diversity of macrofauna in the soil has a relationship with the content of soil organic matter which means that the high diversity of soil macrofauna is determined by the content of soil organic matter in soil. Organic matter is a source of food for macrofauna, the higher soil organic matter content, the higher diversity of macrofauna. Agricultural management strategies to increase earthworm diversity need to be carried out, including increasing the amount of land cover, reducing soil compaction, applying mulch on the soil surface, and increasing the amount of soil organic matter (Haghnazari et al., 2015).

\section{Earthworm Abundance}

The abundance of earthworms in cocoa plantations with several shade patterns indicates the number of individuals varies. The highest abundance of earthworms was found in cocoa plantations with leucaena and areca palm shading, namely 1,536 individuals. $\mathrm{m}^{-2}$, whereas the lowest abundance of earthworms was found in cocoa plantations with leucaena and oil palm shading patterns, namely 128 individuals. $\mathrm{m}^{-2}$ (Figure 1). The abundance of earthworms in leucaena and areca palm shading patterns was higher than in under other shades tested which may be related with organic $\mathrm{C}$ in cocoa plantations with shade tree from leucaena + areca palm was the highest compared to other locations (Table 3). This result is supported by Suin (1989) that macrofauna population is positively correlated with soil organic matter content. Factors that affect the abundance of earthworms are not only soil organic matter content, but also by the dose and type of organic matter (Nurhidayati et al., 2012) and environmental conditions (Nurrohman et al., 2018). 
The family Glossoscolicidae, species Pontoscolex corethrurus was found in all research locations, namely in cocoa plantations with different shade tested which reveals that the level of adaptability of this worm is high. The Megascolicidae family was found only one individual on the soil surface. This was presumably due to the influence of the rain that fell during observations at the cocoa plantation location with paranet shade. The presence of rain caused the soil to become moist eventually that earthworms come out of the soil actively looking for food.

Dwiastuti et al. (2018) stated that during rainy season earthworms were found on the surface of the soil, but during dry season they are more commonly found in soil because the evaporation rate was higher on the surface of the earthworm body so that earthworms penetration into the soil to maintain body moisture. This statement was in accordance to the results of this study where the abundance of worms was found higher under soil surface.

Population (in terms of biomass) of earthworms in cocoa plantations with different shade trees during the experiment which was carried out in dry season is shown in Figure 4. Earthworm biomass in all treatments appeared to be low which indicates that number of founded earthworms found
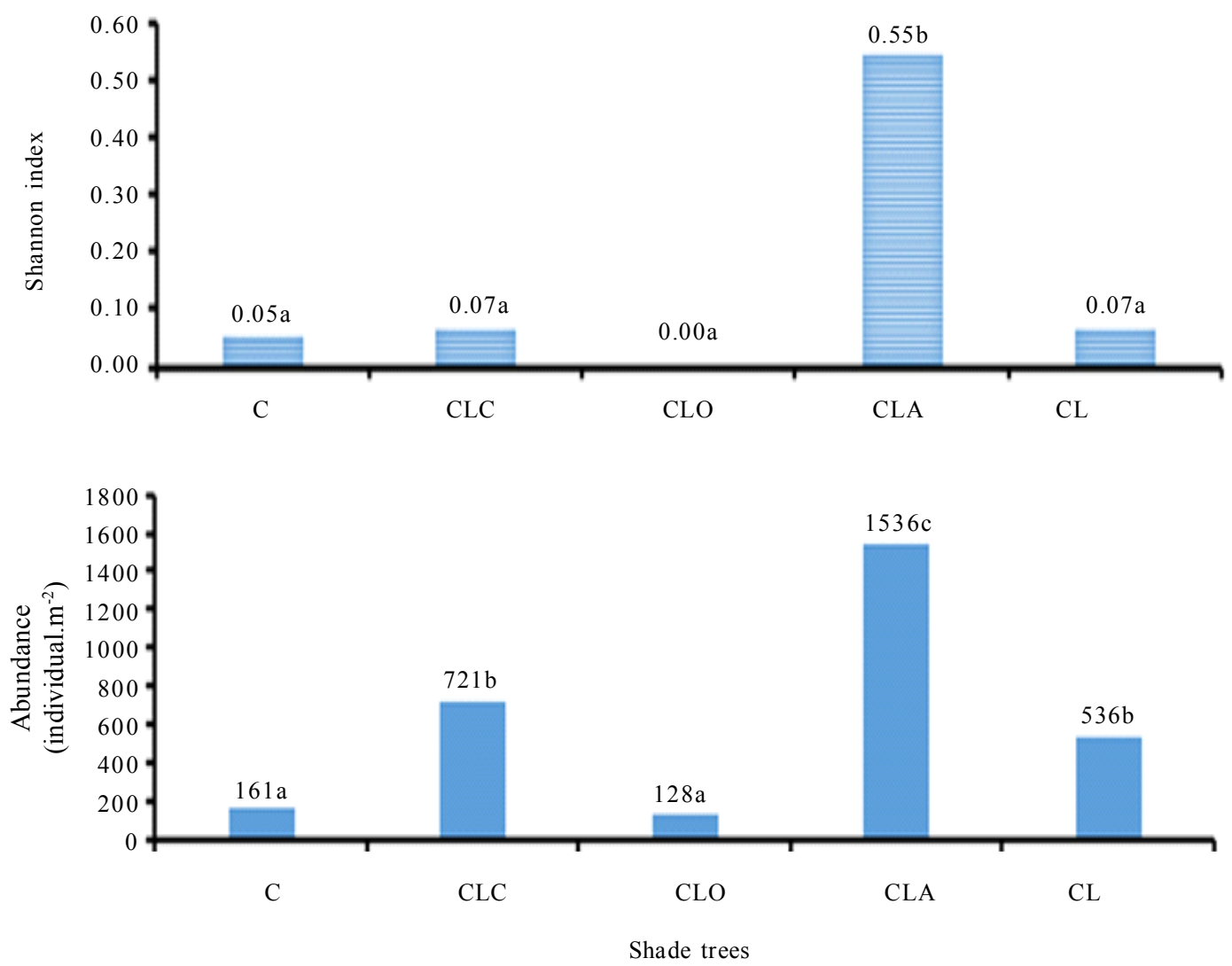

Figure 1. Earthworm diversity based on Shannon index (top) and earthworm abundance (bottom) in cocoa plantations with several shade trees $(\mathrm{C}=\mathrm{Control}(\operatorname{cocoa}+$ paranet $) ; \mathrm{CLC}=\mathrm{Cocoa}+$ leucaena + coconut CLO $=$ Cocoa + leucaena + oil palm; CLA $=$ Cocoa + leucaena + areca palm; CL $=$ Cocoa + leucaena) 
Table 2. Presence and distribution of identified earthworm families in cocoa plantations with several shade trees

\begin{tabular}{lccccc}
\hline \multirow{2}{*}{ Family } & \multicolumn{4}{c}{ Cocoa plantations with several shade trees } \\
\cline { 2 - 5 } & $\begin{array}{c}\text { Control } \\
\text { (cocoa+paranet) }\end{array}$ & $\begin{array}{c}\text { Cocoa+ } \\
\text { leucaena+coconut }\end{array}$ & $\begin{array}{c}\text { Cocoa+leucaena } \\
\text { +oil palm }\end{array}$ & $\begin{array}{c}\text { Cocoa+leucaena } \\
\text { +areca palm }\end{array}$ & $\begin{array}{c}\text { Cocoa+leucaena } \\
\text { Glossoscolecidae }\end{array}$ \\
Megascolecidae & $\mathrm{v}$ & $\mathrm{v}$ & $\mathrm{v}$ & $\mathrm{v}$ \\
\hline Note: $\quad \mathrm{v}=$ learthworm family was found & & & & $\mathrm{v}$ \\
\hline
\end{tabular}

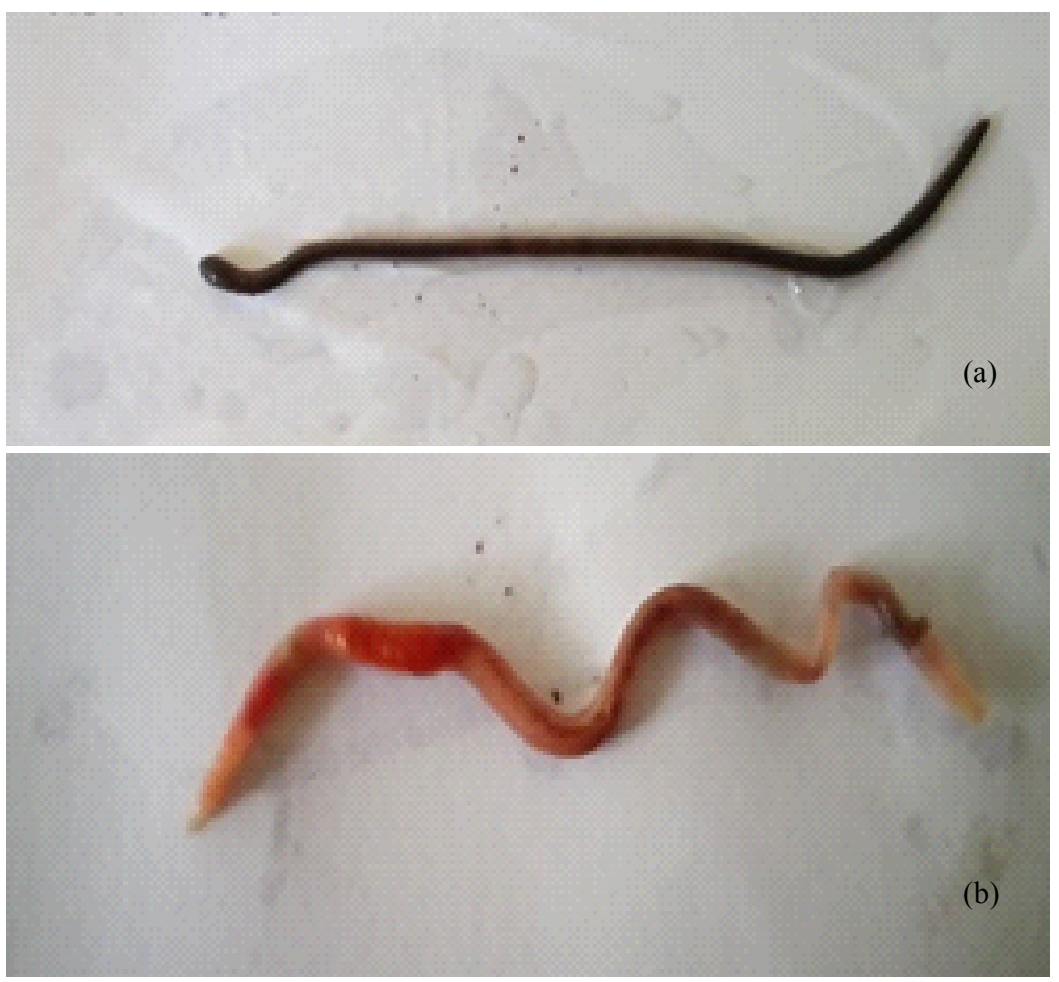

Figure 3. Earthworms family of Megascolocidae (a), and Glossoscolicidae (b) found in experimental sites

was very small (juvenile). Juvenile earthworms were found mostly in soil because during dry season the air and soil temperatures increase therefore more earthworms are found in soil to maintain their body moisture. The results of this study were in accordance with Wibowo (2016) that the diversity of earthworms was largely determined by season. In dry season earthworm diversity was lower than that in the rainy season.
There were only 4 earthworms found during dry season but during rainy season 7 species were found in this study. During dry season many earthworms try to penetrate the soil, but are less able to adapt to hot conditions, and even finally die. Consequently, it was difficult to find earthworms during the dry season (Wibowo, 2016). Sigh et al. (2019) also reported that during the dry season the earthworm population decreased. 
Earthworm biomass in this study was low due to low organic matter content at the experimental sites (Table 2). Organic matter is a food source for the growth and development of earthworms hence with low organic matter content in soil results in low earthworm biomass. Meanwhile, application of 20 ton of cocoa pod husk compost per hectare resulted in the highest earthworm abundance which was about five times higher than the population in control treatment (Prayogo et al., 2020). Ojha et al. (2014) found that the application of organic matter was able to increase the abundance and biomass of earthworms both in rainy and dry seasons.

Large-bodied species cannot withstand at high air temperatures during dry season due to larger body surface related with evaporation. Eartworms penetrate deeper into soil in order to survive during the dry season (Wibowo, 2016) which suggests that much more juveniles are found during the dry season, resulting in low biomass of earthworms despite high abundance.

The difference between wet and dry months is related with differences in earthworm biomass. Research on earthworms in this plantation was also conducted from October 2016 to June 2017 (Yulianti et al., 2018). The population of earthworms in cocoa plants under leucaena was 114 individuals. $\mathrm{m}^{-2}$ with earthworm biomass 47.91 g.m. ${ }^{-2}$. The earthworm biomass was larger (adult) than this study, which was dominated by earthworm biomass of less than 1 g.individual ${ }^{-1}$ (juvenile). In addition, the organic $\mathrm{C}$ content in cocoa plants under leucaena $2.08 \%$ contributed to the larger earthworm biomass (Yulianti et al., 2018).

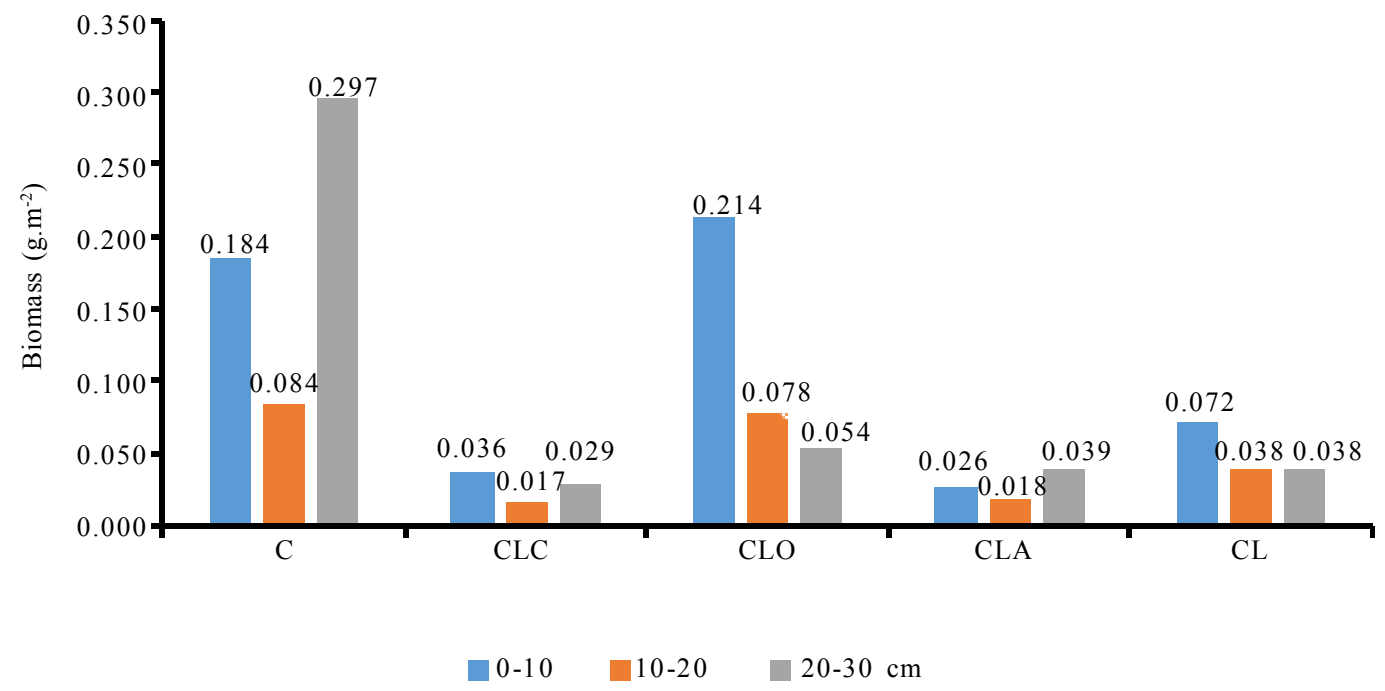

Figure 4. Earthworm biomass at various soil depths in cocoa plantaions with various shade trees $(\mathrm{C}=$ Control; $\mathrm{CLC}=\mathrm{Cocoa}+$ leucaena + coconut CLO $=$ Cocoa + leucaena + oil palm; CLA $=$ Cocoa + leucaena + areca palm; $\mathrm{CL}=\mathrm{Cocoa}+$ leucaena) 


\section{Soil Properties and Earthworm Abundance Relationship}

Soil chemical analysis such as $\mathrm{C}, \mathrm{N}, \mathrm{pH}$, and $\mathrm{Ca}$ were found to be the lowest in the soil layers in cocoa plantations with artificial shade or paranet compared to cocoa plantations with leucaena + coconut, leucaena + areca palm, leucaena + paranet, and leucaena. The variety of litterfall in cocoa plantations with more complete shade contributed to enrich the nutrients in the soil so that it had higher nutrients than the control. Cocoa plantation with paranet shade only have cocoa leaf litter, while cocoa farms with leucaena, areca palm, coconut, and oil palm trees have more various litter. Complex grown cocoa can provide environmental services, including leaf litter, providing nutrient cycling and preventing soil erosion (Brito-Vega et al., 2018). Litterfall in cocoa plantations with shade of coconut, oil palm, areca palm, and leucaena was decomposed by macro-fauna and micro-fauna in the soil, resulting higher nutrient content than paranet shade. The advantages of planting various types of plants or agroforestry were minimizing nutrient loss and maintaining nutrient cycles to the environment (Suryani \& Dariah, 2010).

Organic $\mathrm{C}$ in cocoa plantations with paranet shade is almost half of organic $\mathrm{C}$ in cocoa plantations with leucaena, coconut, oil palm, and areca palm. Similar to organic $\mathrm{C}$, the nitrogen and $\mathrm{Ca}$ values of cocoa plantations with paranet shade were lower than other shade. These nutrients were the result of the decomposition of organic matter originating from litterfall and plant parts such as roots in the soil. The $\mathrm{C} / \mathrm{N}$ ratio of all cocoa plantations with paranet shade and with leucaena, coconut, oil palm, and areca palm did not significanly differ, as well as the soil $\mathrm{pH}$ which was around 6 which means it was somewhat neutral.
Soil organic $\mathrm{C}$ content affects the physical parameters of the soil, namely bulk density and particle density. Cocoa plantation with artificial shade had a higher bulk density than cocoa farms with leucaena, coconut, oil palm, and areca palm because cocoa with control shade had lower organic $\mathrm{C}$ compared to other treatments. This also occurs in the parameters of the particle density. Soil organic $\mathrm{C}$ is able to make soil more friable, changing the compacted soil structure to become lighter. The higher organic $\mathrm{C}$ content in cocoa plantations with leucaena, coconut, oil palm, and areca palm contributed to changing the soil bulk density and particle density to be lighter. Soil porosity parameters were almost uniform in all treatments.

Figure 5 shows the relationship of organic $\mathrm{C}$, soil $\mathrm{N}$ and soil particle density with earthworm abundance. The higher the organic $\mathrm{C}$ content of the soil, the higher the abundance of earthworms. This result is suitable with the statement of Suin (1989) which stated that the macrofauna population was positively correlated with soil organic carbon content. The abundance of earthworms was also positively correlated with the nitrogen content of the soil which was the result of earthworm decomposition. More abundant the earthworm population, will increase organic matter decomposition and affect the availability of soil nitrogen. The results of this study were in accordance with Blouin et al. (2013) who reported that nitrogen mineralization increased in the presence of earthworms. Soil physics analysis, namely soil particle density, showed a negative correlation. Soil particle density that higher make the abundance of earthworms will decrease. A high soil particle density indicates a low organic matter content. Low organic matter affects the abundance of earthworms to be low. 

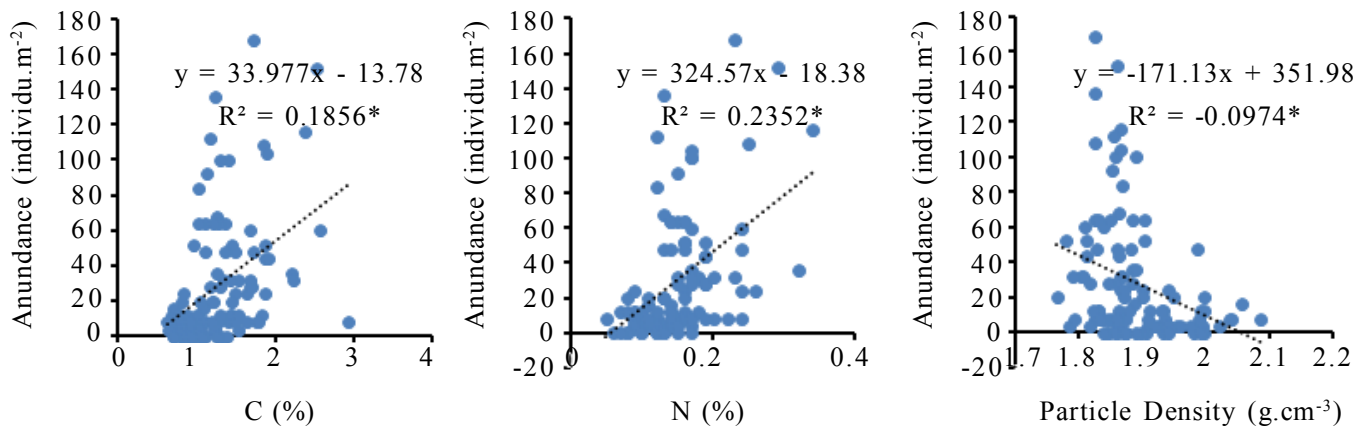

Figure 5. Correlation of soil organic $\mathrm{C}$, total $\mathrm{N}$, and particle density with earthworm abundance in cocoa with soil $\mathrm{C}, \mathrm{N}$, and paricle density

Table 3. Pearson correlation coefficient of soil fraction with earthworm abundance

\begin{tabular}{lccc}
\hline & Sand fraction & Silt fraction & Clay fraction \\
\hline Earthworm abundance & 0.235 & -0.306 & -0.165 \\
\hline
\end{tabular}

Soil texture affects the earthworm abundance. Table 4 shows that the sand and silt fractions have a correlation with the abundance of earthworms. The sand fraction has a positive correlation with the abundance of earthworms. The sand fraction causes soil macro pores is higher and effecting better aeration in the soil. According to Andi et al. (2017) sandy loam soil texture can support the growth of earthworm Pontoscolex coethrurus because it can increase activity, productivity and biomass of earthworms. In contrast, the silt fraction has a negative correlation with earthworm abundance. Silt causes soil pores is smaller and will affect the inhibition of soil aeration.

\section{Microclimate and Earthworm Abundance Relationship}

Earthworms are influenced by environmental conditions such as soil temperature, soil moisture, soil moisture content, and soil pH (Ratnawati et al., 2019). A study on cocoa conducted by Prastowo et al. (2020) showed that soil $\mathrm{pH}$ had a negative correlation with earthworm population which suggested that higher the $\mathrm{pH}$ value, lower the population of earthworms. In this study, observations of microclimate during the dry season 2020 on cocoa plantations with several shade treatments have been carried out. The results of microclimate observations are presented in Table 4.

The observed soil temperature in all cocoa plantations in this study was more than $25^{\circ} \mathrm{C}$ during the dry season. The high soil temperatures affected large earthworms which cannot be found during this experiment. Earthworms found during sampling were dominated by small earthworms, because small earthworms are able to survive with high soil temperatures. According to Salamah et al. (2016), an optimal soil temperature for the development and growth of earthworms is $15-25^{\circ} \mathrm{C}$. Very high or very low temperature may interfere respiration, growth, metabolism, and reproduction of earthworms. The optimal soil moisture for earthworms is $15-50 \%$. In this study, soil moisture was between 20 $30 \%$ meaning that the soil moisture is suitable for the growth of earthworms. 
Air temperature may affect soil temperature, nonetheless, the presence of shade can reduce fluctuation of air temperature and humidity. During this study, the highest air humidity was found in cocoa plantation with paranet shade. Air humidity was lower in cocoa plantations with leucaena, coconut, oil palm, and areca palm shade trees. The light inrtensity in cocoa plantations with paranet shade was $13 \%$, while in cocoa plantations with shade of leucaena + coconut was $27.8 \%$, leucaena + oil palm was $6.4 \%$, leucaena + areca palm was $23.5 \%$, and leucaena was $42.3 \%$. The sun light intensity is lowest in cocoa plantation with paranet shade. The light intensity in cocoa plantations with leucaena + coconut and leucaena + areca palm shading was almost the same, namely $23.5 \%$ and $27.8 \%$, respectively. The ideal light intensity for cocoa is $50-70 \%$ (Wessel, 1985).
Climate factors that have a relationship with the earthworm abundance in the dry season are light intensity and air temperature (Figure 6). The earthworms abundance in soil increased with increasing light intensity. During the dry season, earthworms prefer to be in the soil to maintain body moisture. Mishra et al. (2019) reported that Eisenia fetida showed suppressed growth when exposed to sun light. During the dry season, many earthworms penetrate into the deeper soil to maintain their body moisture. Sigh et al. (2019) reported that increasing air temperature can change soil moisture and temperature regimes that affect earthworm populations. Earthworms are affected by fluctuations in environmental temperature and make colony in optimal habitats for metabolism. During the dry season, earthworms on the ground surface are difficult to be found, but

Table 4. Characteristics of microclimate in cocoa plantations with several shade trees in July-October 2020

\begin{tabular}{lccccc}
\hline Cocoa shade type & $\begin{array}{c}\text { Soil } \\
\text { temperature } \\
\left({ }^{\circ} \mathrm{C}\right)\end{array}$ & $\begin{array}{c}\text { Soil } \\
\text { moisture } \\
(\%)\end{array}$ & $\begin{array}{c}\text { Air } \\
\text { temperature } \\
\left({ }^{\circ} \mathrm{C}\right)\end{array}$ & $\begin{array}{c}\text { Air } \\
\text { humidity } \\
(\%)\end{array}$ & $\begin{array}{c}\text { Light } \\
\text { intensity } \\
(\%)\end{array}$ \\
\hline Control (Paranet) & 26.4 & 30.5 & 28.5 & 82.2 & 13 \\
Cocoa + leucaena + coconut & 26.2 & 20.5 & 29.5 & 68.9 & 27.8 \\
Cocoa + leucaena + oil palm & 25.7 & 29.6 & 29.6 & 72.9 & 6.4 \\
Cocoa + leucaena + areca palm & 25.4 & 26.2 & 26.5 & 76.5 & 23.5 \\
Cocoa + leucaena & 29.5 & 27.5 & 31.4 & 65.7 & 42.3 \\
\hline
\end{tabular}
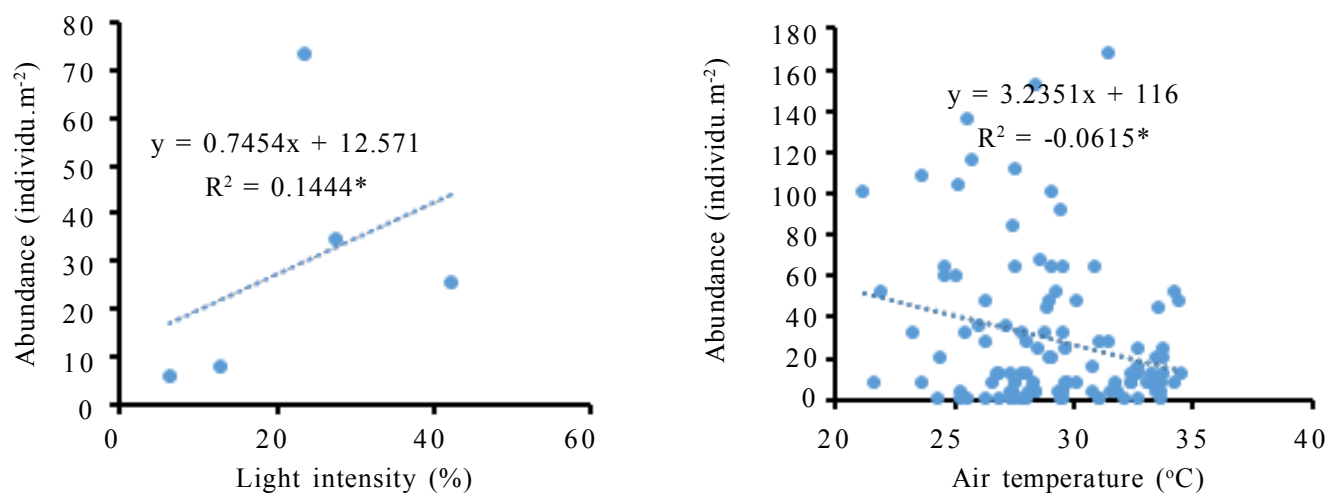

Figure 6. Correlation of light intensity and air temperature with earthworm abundance 
in this study one individual earthworm of the Megascolicidae family belong to Pheretima sp. species was found in a cocoa with paranet shade.

\section{CONCLUSIONS}

Diversity of earthworms in cocoa plantations with paranet, areca palm + leucaena, coconut + leucaena, oil palm shade + leucaena, and leucaena shade is low. The identified families were Glososscolicidae and Megascolocidae. The highest abundance of earthworms was found in areca palm + leucaena shade trees. Soil organic C, N, and sand fraction had positive correlation with earthworm abundance, while soil particle density and silt and clay fraction had a negative correlation. Light intensity had positive correlation with the abundance of earthworms while the air temperature had negative correlation.

\section{REFFERENCES}

Andi; T. Sabrina \& M. Sembiring (2017). Perkembangan cacing Pontoscolex corethrurus pada media kultur dengan berbagai jenis tekstur tanah dan bahan organik. Jurnal Agroekoteknologi, 5, 329-337.

Blouin, M.; K.R. Butt; M.E. Hodson \& L. Dendooven (2013). A review earthworm impact on soil function and ecosystems services. European Journal of Soil Science, 64, 161-182.

BPT (2007). Metode Analisis Biologi Tanah. Balai Besar Litbang Sumberdaya Lahan Pertanian, Badan Penelitian dan Pengembangan Pertanian, Departemen Pertanian, Bogor.

Brito-Vega, H; J.M. Salaya-Dominguez; E. GomezMendez; A. Gomez-Vasquez \& J.B. AnteleGomez (2018). Physico-chemical proper- ties of soil and pods (Theobroma cocoa $\mathrm{L}$.) in cocoa agroforestry systems. Journal of Agronomy, 17, 48-55.

Dewi, W.S. \& M. Senge (2015). Earthworm diversity and ecosystem services under threat. Reviews in Agricultural Science, 3, 25-35.

Dwiastuti, S.; S. Widoretno \& P. Karyanto (2018). Identifikasi cacing tanah dan interaksinya dengan lingkungan lahan berkapur. Jurnal Biogenesis, 14, 23-28.

Endarwati, M.A.; S.W. Kurniawan \& D. Suprayoga (2017). Biodiversitas vegetasi dan fungsi ekosistem: Hubungan antara kerapatan, keragaman vegetasi, dan infiltrasi tanah pada inceptisol lereng Gunung Kawi Malang. Jurnal Tanah dan Sumberdaya Lahan, 4, 577-588.

Firmansyah; T.R. Setyawati \& A.H. Yanti (2017). Struktur komunitas cacing tanah (kelas Oligochaeta) di kawasan hutan Desa Mega Timur Kecamatan Sungai Ambawang. Jurnal Protobiont, 6, 108-117.

Gamasika, F.; S. Yusnaini; A. Niswati \& Dermiyati (2017). Populasi dan biomassa cacing tanah pada berbagai vegetasi di setiap kemiringan lereng serta korelasinya terhadap kesuburan tanah di Laboratorium Lapang Terpadu Fakultas Pertanian Universitas Lampung. Jurnal Agroteknologi Tropika, 5, 169-174.

Haghnazari, F.; S. Hassan \& F. Mehdi (2015). Factor affecting the infiltration of agricultural soils: A review. International Journal of Agronomy and Agricultural Research, 6, 21-35.

Hairiah, K. \& F. Karima (2017). Identifikasi Cacing Tanah Berdasarkan Penciri Eksternal (Morfologi). Universitas Brawijaya, Malang.

Hazriyal, Y.; A. Anhar \& A. Karim (2013). Evaluasi karakteristik lahan dan produksi cocoa di Kecamatan Peudawa dan Peunaron Kabupaten Aceh Timur. Jurnal Manajemen Sumberdaya Lahan, 4, 579-590. 
Kilowasid, L.M.H.; T.S. Syamsudin; F.X. Susilo \& E. Sulistyawati (2012). Ecological diversity of soil fauna as ecosystem engineers in smallholder cocoa plantation in South Konawe. Journal Tropical Soils, 17,173-180.

Mishra, C.S.K.; S. Nayak \& S. Sama (2019). Low intensity light effect on survivability, biomass, tissue protein and enzim activities of earthworm Eudrilus euginae (Kinberg). International Scholars Journal, 16, 8-14.

Nurrohman E.; R. Abdulkadir \& W. Sri (2018). Studi hubungan keanekaragaman makrofauna tanah dengan kandungan $\mathrm{C}$ organik dan organophoshat tanah di perkebunan cokelat (Theobroma cacao L.) Kalibaru, Banyuwangi. Bioeksperimen, 4, 1-10.

Odum, E.P. (1993). Dasar-dasar Ekologi. (Terjemahan). Edisi Ketiga. Yogyakarta. Gadjah Mada University Press.

Ojha, R.B.; S.C. Shah; K.R. Pande \& D.D. Dhakal (2014). Soil properties and earthworm population dynamic influenced by organic manure in winter and spring season at Rampur, Chitwan, Nepal. International Journal of Applied Sciences and Biotechnology, 2, 193-198.

Prastowo, E.; L.D. Agustina \& C. Prayogo (2020). Earthworm abundance and soil characteristics following cocoa waste and manure applications. Pelita Perkebunan, 36(1), 47-55.

Prayogo, C.; L.D. Agustina; E. Prastowo; J.B. Baon $\&$ N. Arfarita (2020). Utilization of composted cocoa husk for improving earthworm population and their relationship to cocoa production (Theobroma cacao L.). Proceedings of International Conference on Green Agroindustry and Bioeconomy. IOP Conference Series, Malang.
Ratnawati, S.; N.S.N. Handayani \& Trijoko (2019). Keragaman jenis cacing tanah di Kebun Biologi Universitas Gadjah Mada. Jurnal Biologi Universitas Andalas, 7, 126-135.

Salamah, M.H.; A. Niswati; Dermiyati \& S. Yusnaini (2016). Pengaruh sistem olah tanah dan pemberian mulsa bagas terhadap populasi dan biomassa cacing tanah pada lahan pertanaman tebu tahun ke-5. Jurnal Agrotek Tropika, 4, 222-227.

Setyaningsih, H.; K. Hairiah \& W.S. Dewi (2014). Respon cacing penggali tanah Pontoscolex corethrurus terhadap berbagai seresah. Jurnal Tanah dan Sumberdaya Lahan, 1, 63-72.

Sigh, J.; C.D. Willian; M. Schadler \& G.G. Brown (2019). Climate change effects on earthworms: A Review. Soil organisms, 91, 114-138.

Suin, M.N. (1989). Ekologi Hewan Tanah. Bumi Aksara, Bandung.

Suryani, E. \& A. Dariah (2010). Peningkatan produktivitas tanah melalui sistem agroforestri. Jurnal Sumberdaya Lahan, 6, 101-109.

Wessel, M. (1985). Shades and nutrition. In: Cocoa (G.A.R. Wood \& R.A. Lass, Eds.), Longman Group Ltd., Essex.

Wibowo, S. (2016). Keragaman cacing tanah pada lahan dengan berbagai masukan bahan organik di daerah Lampung Utara. Jurnal AGRI PEAT, 17, 106-114.

Yulianti, T.; S. Abdoellah; D. Suprayogo \& N.P. Sari (2018). Cocoa production as affected by shade tree species and soil on Quality. Pelita Perkebunan, 34, 80-89.

$$
* * 0 * *
$$

